\title{
Faktor Pencetus Kejadian Alergi Pernapasan Pada Pasien Dewasa Di RSUPN Dr. Cipto Mangunkusumo
}

\section{The Triggering Factors of Respiratory Allergiesin Adult Patients at the RSUPN Dr. Cipto Mangunkusumo}

FITHRIYAH NUR KURNIA ${ }^{1}$, ALEX HARTANA ${ }^{*}$, IRIS RENGGANIS ${ }^{2}$

\author{
'Departemen Biologi, Fakultas Matematika dan Ilmu Pengetahuan Alam, Institut Pertanian Bogor, \\ Kampus IPB Dramaga, Bogor 16680 \\ ${ }^{2}$ Rumah Sakit Umum Pusat Nasional Dr. Cipto Mangunkusumo, Jakarta, Indonesia
}

Diterima 29 Juli 2019/Disetujui 23 September 2019

\begin{abstract}
Allergy is a hypersensitive reaction in human due to human body produced IgE antibody more than regullary do as a response to the presence of allergens. Asthma and rhinitis are respiratory allergies, could be caused by genetics and environmental factors. The objectives of this study was to analyze the trigger factors of asthma and rhinitis patients at the Allergy-Immunology Polyclinic, Internal Medicine Department, Faculty of Medicine, University of Indonesia, Dr. Cipto Mangunkusumo National Center General Hospital, Jakarta. The skin test using grass mix pollen, cat, dog, cockroach, and dust mites allergens were done to 90 respiratory allergy patients. History of respiratory allergy from their parents, and environmental factors such as pets, cigarette smoke, and emotional state were asked and recorded. The patients mostly women, and most respiratory allergy patients could be detected by skin test using dust mites allergens, however, their reaction did not the same for other allergens. More than $\mathbf{5 0 \%}$ patients of respiratory allergy have atopy from their parents, for most of patients, their emotional state and cigarette smoke in house could trigger the symptom of respiratory allergy.
\end{abstract}

Key words: allergen, allergy, asthma, rhinitis, dust mites

\section{PENDAHULUAN}

Latar Belakang. Alergi merupakan penyakit berupa reaksi yang dihasilkan dalam waktu singkat oleh imun tubuh akibat adanya suatu bahan yang berada di lingkungan yang disebut sebagai alergen. Alergi dapat terjadi karena tubuh memproduksi antibodi IgE (Imunoglobulin E) spesifik secara berlebih sebagai respon imun tubuh terhadap adanya paparan alergen (Schoefer et al. 2008). Alergen umumnya tidak berbahaya dan banyak terdapat di lingkungan. Reaksi alergi bermula pada tubuh yang terkena paparan alergen lalu menimbulkan respon untuk memproduksi IgE kemudian IgE akan menempel pada sel mastosit yang mengandung mediator yang dapat memicu terjadinya reaksi alergi. Bila tubuh terkena paparan kembali dengan alergen yang sama maka alergen tersebut akan berikatan dengan IgE yang menempel pada sel mastosit. Ikatan yang terjadi antara alergen dan antibodi IgE

*Penulis korespondensi:

E-mail: ahartana301249@gmail.com memicu sel mastosit menjadi aktif kemudian pecah dan melepaskan mediator seperti histamin, leukotrin, dan mediator lainnya yang dapat menimbulkan inflamasi berupa gejala klinis alergi (Hikmah dan Dewanti 2010; Mennella dan Dickstein 2016).

Manifestasi alergi pada manusia dapat terjadi di organ pernapasan berupa asma dan rinitis. Asma merupakan penyakit inflamasi kronik jalur napas bagian bawah yang ditandai dengan gejala episodik yaitu sesak napas atau dada terasa sesak, batuk, dan mengik (Price et al. 2017). Penyakit alergi pernapasan selain asma adalah rinitis. Penderita rinitis mengalami inflamasi di daerah hidung atau saluran napas bagian atas yang ditandai dengan bersin berulang, hidung terasa gatal dan tersumbat, serta mengeluarkan cairan jernih (rhinorrhea) (Lampalo et al. 2017). Asma dan rinitis dapat terjadi bersamaan karena terjadi pada satu jalur saluran pernapasan. Penderita asma dan rinitis ditandai dengan gejala khas seperti dada sesak atau sesak napas, mengik, rhinorrhea, hidung gatal serta tersumbat, dan bersin berulang.

Jumlah penderita alergi pernapasan mengalami peningkatan. Penderita asma di dunia sekitar 235 
juta orang (WHO 2017). Menurut survei dari Riset Kesehatan Dasar, penduduk Indonesia yang menderita asma pada tahun 2008 sekitar 3.5\% dan di Jakarta sekitar $2.9 \%$ (Balitbangkes 2008), kemudian di tahun 2013 penderita asma di Indonesia meningkat menjadi $4.5 \%$ dan di DKI Jakarta menjadi $5.2 \%$ (Balitbangkes 2013). Selain asma, prevalensi rinitis alergi juga meningkat selama 50 tahun terkahir (Bousquet et al. 2008). Hasil survei dari 986,532 jiwa penduduk Indonesia, yang menderita rinitis sebesar 239,727 jiwa, dan di DKI Jakarta dari sekitar 16,970 penduduk, sebanyak 6,397 jiwa menderita rinitis (Balitbangkes 2008).

Alergi pernapasan dapat timbul karena adanya faktor genetik dan lingkungan. Faktor genetik didapatkan dari riwayat atopi orang tua. Atopi merupakan faktor genetik yang diwariskan dalam keluarga berupa kontrol antibodi $\operatorname{IgE}$ sebagai respon terhadap alergen dosis rendah (Johansson et al. 2004). Orang tua yang menderita alergi pernapasan cenderung memiliki anak yang menderita alergi pernapasan juga. Selain faktor genetik, lingkungan juga berpengaruh terhadap timbulnya alergi pernapasan. Alergen yang berada di lingkungan dapat menjadi pencetus timbulnya alergi pernapasan.

Menurut cara masuk alergen, alergen terbagi menjadi 4 jenis yaitu alergen yang masuk bersama komponen udara yang terhirup (inhalan), alergen dari makanan yang dikonsumsi lalu masuk ke saluran pencernaan (ingestan), alergen yang masuk ke tubuh melalui suntikan (parenteral), dan alergen yang masuk melalui kontak dengan kulit atau jaringan mukosa (kontaktan) (Wistiani dan Notoatmojo 2011). Alergen pencetus terbanyak yang menimbulkan alergi pernapasan adalah alergen inhalan seperti serbuk sari, tungau debu rumah, kecoa, dan hewan peliharaan (Rengganis et al. 2008; Utama 2010). Sensitivitas seseorang terhadap alergen inhalan dapat diketahui melalui uji tusuk kulit atau Skin Prick Test (Sellaturay et al. 2015). Skin Prick Test digunakan untuk mendeteksi adanya antibodi IgE spesifik terhadap alergen yang masuk ke dalam tubuh. Keuntungan uji tusuk kulit yaitu murah, efek samping tidak berbahaya, reaksinya cepat yaitu 15 menit setelah penetesan alergen, dan hasilnya dapat terlihat selama tes dilakukan (Bousquet et al. 2012).

Selain alergen, faktor lingkungan yang berpengaruh terhadap kejadian alergi pernapasan adalah faktor non-alergen seperti keadaan emosi penderita dan paparan asap rokok. Menurut penelitian Herdi (2011), dilaporkan 52\% faktor pencetus serangan asma berupa asap rokok, dan di Taipei sebanyak $59 \%$ faktor pencetus penderita asma berupa perubahan emosi (Chiang et al. 2005). Pengendalian diri diperlukan agar mengurangi kontak dengan faktor pencetus timbulnya alergi pernapasan. Pengendalian diri dilakukan dengan cara mengetahui alergen spesifik, faktor non-alergen, dan faktor genetik yang kemungkinan berpengaruh terhadap kejadian alergi pernapasan.

Tujuan. Penelitian ini bertujuan menganalisa faktor pencetus serangan asma dan rinitis pada pasien alergi pernapasan melalui uji tusuk kulit dan wawancara di Poliklinik Alergi-Imunologi, Departemen Ilmu Penyakit Dalam, Fakultas Kedokteran Universitas Indonesia, Rumah Sakit Umum Pusat Nasional Dr. Cipto Mangunkusumo (FKUI/RSUPN-CM).

\section{BAHAN DAN METODE}

Waktu dan Tempat. Penelitian dilakukan pada bulan Febuari hingga April 2017 di Poliklinik dan Ruang Prosedur Alergi-Imunologi, Departemen Ilmu Penyakit Dalam, FKUI/RSUPN-CM.

Subjek Penelitian. Subjek penelitian adalah pasien alergi yang datang ke Poliklinik AlergiImunologi, Departemen Ilmu Penyakit Dalam, FKUI/RSUPN-CM dari bulan Febuari 2017 hingga April 2017. Kriteria subjek penelitian adalah pasien yang telah didiagnosa oleh dokter menderita alergi pernapasan seperti asma, rinitis, atau asma dan rinitis, berusia 18-59 tahun, bersedia mengikuti penelitian dengan menandatangani formulir persetujuan setelah mendapatkan penjelasan, bersedia dilakukan pemeriksaan uji tusuk kulit dan wawancara, bebas obat anti histamin selama 7 hari, tidak sedang hamil atau menyusui, tidak memiliki penyakit ginjal kronik, autoimun, keadaan kulit yang sensitif terhadap tekanan dan garukan (dermatographism), dan kontraindikasi uji tusuk kulit lainnya.

Bahan dan Alat. Bahan yang digunakan dalam penelitian adalah alergen uji tusuk kulit merk Stallergenes yang terdiri atas satu alergen serbuk sari rumput, dua alergen hewan peliharaan (kucing dan anjing), tiga alergen tungau debu (Blomia tropicalis, Dermatophagoides farinae, dan Dermatophagoides pteronyssinus), satu alergen kecoa, dua botol kontrol yaitu kontrol positif (histamine) dan kontrol negatif (temoin), dan swab alkohol 70\%.

Alat yang digunakan dalam penelitian ini adalah jarum khusus merk Terumo Needleberukuran $0.45 \times 13 \mathrm{~mm}$ sebagai penusuk agar alergen dapat masuk ke dalam kulit, ballpoint untuk menandai tempat penetesan alergen, penggaris untuk mengukur hasil reaksi, tisu untuk membersihkan tetesan alergen pada lengan, senter sebagai cahaya bantu penerangan, lembar kuisioner dan hasil uji tusuk kulit, serta alat tulis.

\section{Prosedur Penelitian.}

Pengumpulan Responden. Pasien yang berkunjung ke Poliklinik Alergi-Imunologi, Departemen Ilmu Penyakit Dalam, FKUI/RSUPN-CM meliputi pasien 
baru dan kontrol. Pasien baru merupakan pasien yang baru pertama kali datang ke Poliklinik AlergiImunologi dianamnesis oleh dokter dan didiagnosa menderita alergi pernapasan tetapi belum diwawancara dan belum diuji tusuk kulit, sedangkan pasien kontrol adalah pasien yang sudah di diagnosa alergi pernapasan yang datang kembali untuk keperluan pengobatan ketika penelitian berlangsung. Pasien kontrol ada yang sudah pernah diuji tusuk kulit 6 bulan terakhir dan ada yang belum diuji tusuk kulit. Pasien kontrol yang pernah mendapat uji tusuk kulit dalam jangka waktu lebih dari 6 bulan akan diuji tusuk kulit kembali.

Wawancara. Pasien yang memenuhi kriteria penelitian akan diwawancara untuk mendapatkan data kuisioner yang melengkapi data uji tusuk kulit. Sebelum diwawancara, pasien diberikan penjelasan mengenai prosedur penelitian dan menandatangani lembar persetujuan sebagai responden penelitian. Setelah menandatangani lembar persetujuan dilanjutkan dengan wawancara. Pasien diwawancarai dengan ditanyai nama, tempat dan tanggal lahir, nomor telepon rumah atau telepon selular untuk kepentingan lebih lanjut (follow-up), jenis kelamin, usia, ada tidaknya riwayat alergi yaitu asma dan atau rinitis dari orang tua, dan apakah keadaan emosional mempengaruhi timbulnya alergi pernapasan. Keadaan emosional pasien berupa kecemasan pasien terhadap suatu keadaan atau perasaan kesal terhadap seseorang. Selain itu, pasien diwawancara mengenai ada tidaknya keberadaan hewan peliharaan di dalam rumah seperti anjing dan kucing, apakah pasien merokok, ada tidaknya anggota keluarga di dalam rumah yang merokok, dan apakah alergi pernapasan akan timbul jika terkena paparan asap rokok. Data dicatat dalam lembar kuisioner.

Uji Tusuk Kulit (Skin Prick Test). Pasien yang sudah diwawancara, selanjutnya di antar ke Ruang Prosedur Alergi-Imunologi, Departemen Ilmu Penyakit Dalam, FKUI/RSUPN-CM untuk dilakukan uji tusuk kulit. Pasien kontrol yang sudah pernah di uji tusuk kulit dalam periode enam bulan terakhir tidak dilakukan uji kembali.Uji tusuk kulit diawali dengan kulit lengan bawah bagian dalam pasien dibersihkan dengan swab alkohol 70\% agar steril dan dibiarkan sampai kering. Tempat penetesan alergen diberi tanda tinta menggunakan ballpoint. Masing-masing alergen ditetesi di tempat yang sudah diberi tanda (Gambar 1a), jarum khusus ditusukkan ke tetesan alergen secara tegak lurus (Gambar 1b), dan dibiarkan selama 15 menit. Setiap jarum hanya dipakai satu kali untuk satu jenis alergen.

Setelah 15 menit, lengan bawah bagian dalam yang terdapat tetesan alergen dibersihkan dengan tisu agar memudahkan untuk pengukuran hasil reaksi. Hasil reaksi uji tusuk kulit di ukur menggunakan penggaris, dan senter sebagai alat bantu penerangan. Reaksi positif akan tampak berupa bentol pada area tusuk dengan diameter bentol berukuran $\geq 3 \mathrm{~mm}$ (Sellaturay et al. 2015), sedangkan reaksi negatif berupa bentol dengan ukuran $<3 \mathrm{~mm}$ atau tidak sama sekali menimbulkan bentol (Gambar 2). Setelah diperoleh hasil uji tusuk kulit, pasien dianjurkan untuk mencuci lengan tangan dengan air agar tidak ada sisa alergen yang tertinggal. Data yang diperoleh dicatat di lembar hasil uji tusuk kulit. Seluruh data yang dicatat pada lembar kuisioner dan hasil uji tusuk kulit akan di tabulasikan di Microsoft Excel 2007.

\section{HASIL DAN PEMBAHASAN}

Wawancara dilakukan terhadap 90 pasien alergi pernapasan yang berkunjung ke Poliklinik Alergi-

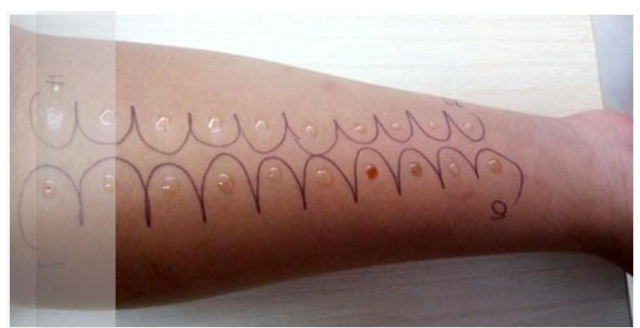

a

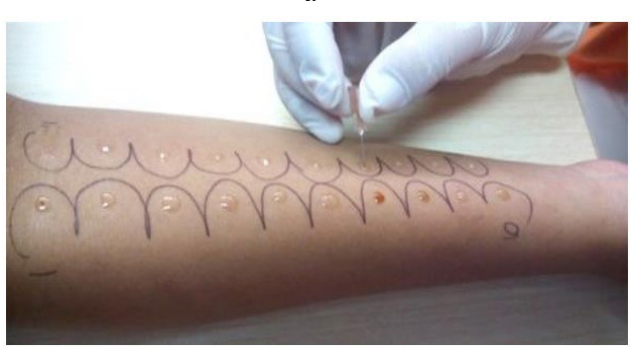

b

Gambar 1. (a) Alergen diteteskan pada tempat penetesan, (b) jarum ditusukkan pada tetesan alergen

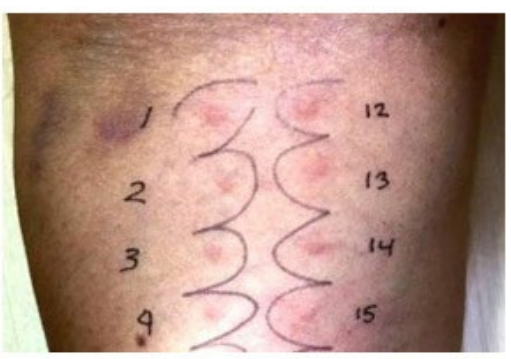

a

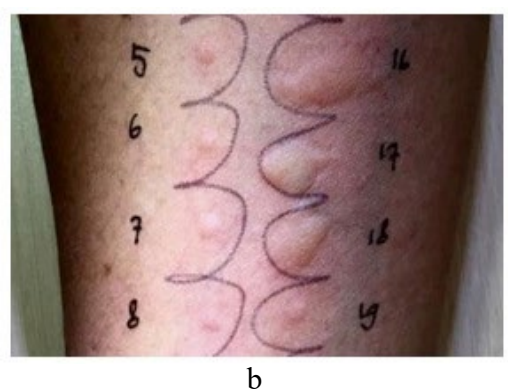

Gambar 2. (a) Reaksi negatif ditandai tidak adanya bentol, (b) reaksi positif ditandai adanya bentol 
Imunlogi, Departemen Ilmu Penyakit Dalam, FKUI/ RSUPN-CM yang terdiri dari 12 penderita rinitis dan 78 penderita asma. Penderita asma dibedakan menjadi 63 penderita asma saja dan 15 penderita asma disertai rinitis (Tabel 1). Pasien yang berkunjung sebagian besar menderita alergi pernapasan berupa asma.

Pasien penderita asma yang berjumlah 63 orang terdiri atas 47 orang perempuan dan 16 orang laki-laki. Pasien penderita rinitis yang berjumlah 12 orang terdiri dari 9 orang perempuan dan 3 orang laki-laki, sama halnya dengan 15 orang pasien penderita asma disertai rinitis yang terdiri dari 12 orang perempuan dan 3 orang laki-laki sehingga bisa dikatakan jumlah pasien alergi pernapasan pada perempuan lebih banyak dibandingkan laki-laki (Tabel 2). Penelitian sebelumnya dilaporkan di Jakarta, dari 107 penderita asma, sebanyak 69 orang diantaranya adalah perempuan (Atmoko et al. 2011) dan di Medan juga dilaporkan dari 62 penderita rinitis, sebanyak 54 orang adalah perempuan (Lumbanraja 2007).

Perempuan lebih patuh dalam berobat sehingga kedatangannya lebih banyak dibandingkan lakilaki (Ferliani et al. 2015). Perempuan juga rentan mengalami stress dan perubahan kadar hormon. Fluktuasi hormon pada perempuan seperti hormon estrogendan progesteron berpengaruh pada sel yang memicu terjadinya proses inflamasi kemudian terjadi peningkatan kadar mediator inflamasi sehingga terjadi reaksi inflamasi pada mukosa hidung dan saluran pernapasan bawah (Hamano et al. 1998; Vrieze et al. 2007). Perubahan hormon juga dipicu oleh keadaan stress. Stress menimbulkan keadaan cemas dan depresi yang berpengaruh terhadap kadar hormon dalam tubuh yang kemudian terjadi ketidakseimbangan imun sehingga tubuh mengalami peningkatan respon terhadap alergen yang ada di lingkungan yang dapat

Tabel 1. Jumlah pasien penderita alergi pernapasan di Poliklinik Alergi-Imunologi RSUPN-CM

\begin{tabular}{lc}
\hline Penyakit & Pasien penderita (orang) \\
\hline Rinitis & 12 \\
Asma & 63 \\
Asma disertai rinitis & 15 \\
\hline Jumlah & 90 \\
\hline
\end{tabular}

memicu terjadinya reaksi inflamasi pada saluran napas (Chen dan Miller 2007). Selain itu, pertumbuhan dan fungsi paru-paru pada laki-laki lebih berkembang daripada perempuan sehingga penyakit pernapasan lebih berpeluang di derita oleh perempuan (Osman 2003).

Kelompok usia pasien penderita asma mulai dari 18 tahun sampai 59 tahun dan lebih banyak berada pada usia lebih dari 40 tahun sehingga dapat dikatakan serangan asma lebih sering di alami oleh pasien pada usia dewasa daripada remaja (Atmoko et al 2011; Priyanto et al. 2011), begitu juga dengan penderita asma disertai rinitis, pada sebagian besar pasien berusia lebih dari 42 tahun, sedangkan pasien penderita rinitis saja pada perempuan mayoritas berusia mulai dari 18 tahun dan pasien penderita rinitis laki-laki hanya terdapat 3 orang, masing- masing berusia 18-23 tahun, 42-47 tahun, dan 54-59 tahun (Tabel 2). Saat usia dewasa, pertumbuhan dan fungsi paru-paru lebih berakselerasi dalam tubuh dan otot dinding saluran pernapasan lebih kuat terutama pada laki-laki, pada perempuan hormon dalam tubuh lebih matang serta mengalami perubahan kadarnya terutama saat masa menstruasi dan menopause sehingga peluang terjadinya alergi pernapasan lebih besar (Osman 2003; Postma 2007). Selain itu, pada usia dewasa orang lebih banyak berada di lingkungan yang mudah terkena paparan alergen seperti lingkungan sekolah, pekerjaan, dan tempat yang berdebu dengan ventilasi yang kurang baik sehingga peluang untuk timbulnya alergi pernapasan akibat terkena paparan alergen lebih besar (Utama 2010).

Penderita alergi pernapasan biasanya berhubungan dengan faktor genetik yaitu riwayat penyakit dalam keluarganya yang diwariskan atau dikenal sebagai atopi dari orang tuanya (Alford et al. 2004). Pasien penderita asma dan asma yang disertai rinitis yang berkunjung ke RSUPN-CM lebih dari 50\% mempunyai riwayat alergi pernapasan pada orang tuanya (Tabel 3). Penderita asma yang memiliki riwayat keturunan asma sebesar $56 \%$ yang terdiri atas $35 \%$ memiliki ibu yang menderita asma dan $21 \%$ memiliki bapak penderita asma, sedangkan pada pasien asma disertai rinitis yang

Tabel 2. Pasien penderita alergi pernapasan berdasarkan usia dan jenis kelamin di Poliklinik Alergi-Imunologi RSUPN-CM

\begin{tabular}{|c|c|c|c|c|c|c|}
\hline \multirow{2}{*}{ Usia } & \multicolumn{2}{|c|}{ Asma (N) } & \multicolumn{2}{|c|}{ Rinitis (N) } & \multicolumn{2}{|c|}{ Asma disertai rinitis $(\mathrm{N})$} \\
\hline & Perempuan & Laki-laki & Perempuan & Laki-laki & Perempuan & Laki-laki \\
\hline $18-23$ & 4 & 3 & 3 & 1 & 0 & 0 \\
\hline $24-29$ & 1 & 1 & 1 & 0 & 2 & 0 \\
\hline $30-35$ & 4 & 1 & 1 & 0 & 1 & 0 \\
\hline $36-41$ & 6 & 0 & 1 & 0 & 2 & 0 \\
\hline $42-47$ & 9 & 2 & 0 & 1 & 4 & 1 \\
\hline $48-53$ & 9 & 4 & 1 & 0 & 3 & 1 \\
\hline 54-59 & 14 & 5 & 2 & 1 & 0 & 1 \\
\hline Jumlah & 47 & 16 & 9 & 3 & 12 & 3 \\
\hline
\end{tabular}


memiliki riwayat keturunan alergi pernapasan sebesar $87 \%$ yang terdiri atas $33 \%$ riwayat alergi pernapasan berasal dari ibu dan 54\% dari bapak. Jumlah pasien rinitis kurang dari separuh yang orang tuanya juga menderita rhinitis alergi (Tabel 3). Pengetahuan pasien mengenai rinitis masih dikatakan kurang karena gejala rinitis hampir sama dengan gejala penyakit flu sehingga tidak dianggap sebagai penderita rinitis alergi. Selain itu, kemungkinan orang tua dengan gejala rinitis tidak merasa mengalami alergi sehingga dinyatakan orang tua tidak mempunyai riwayat rinitis alergi.

Penelitian di Padang melaporkan dari 44 pasien penderita asma, 23\% memiliki ibu yang juga asma (Usman et al. 2015). Riwayat asma yang dimiliki anggota keluarga generasi pertama dicurigai sebagai faktor penyebab kejadian asma untuk generasi berikutnya (Burke et al. 2003). Selain riwayat penyakit yang diwariskan dari ibu, bapak yang memiliki riwayat alergi pernapasan cenderung mempunyai anak yang berisiko menderita asma dan rinitis alergi juga (Alford et al. 2004; Ludfi et al. 2012). Beberapa kromosom yang diduga berkaitan dengan pewarisan atopi asma adalah kromosom 5, 6, 11q, 12, dan 13q14, sedangkan kromosom 2, 3, 4, dan 9 bekaitan dengan pewarisan atopi rinitis alergi (Cookson dan Moffatt 2000; Davila et al. 2009).

Selain faktorgenetik, adanya paparan alergen spesifik di lingkungan juga berpengaruh terhadap timbulnya gejala alergi pernapasan. Sensitivitas penderita alergi pernapasan terhadap alergen-alergen spesifik seperti serbuk sari rumput, tungau debu, kucing, anjing, dan kecoa dapat diketahui melalui uji tusuk kulit. Hasil uji tusuk kulit pasien asma, rinitis, dan asma disertai rinitis di Poliklinik Alergi-Imunologi RSUPN-CM sebagian besar positif terhadap alergen tungau debu yaitu Blomia tropicalis, Dermatophagoides farinae, dan Dermatophagoides pteronyssinus (Tabel 4), penelitian Alimuddin (2017), dari 101 pasien alergi pernapasan, lebih dari $50 \%$ penderita sensitif terhadap Blomia tropicalis, Dermatophagoides farinae, dan

Tabel 3. Pasien penderita alergi pernapasan berdasarkan riwayat atopi orang tua di Poliklinik Alergi-Imunologi RSUPN-CM

\begin{tabular}{lccc}
\hline \multirow{2}{*}{ Atopi orang tua } & \multicolumn{3}{l}{ Pasien penderita alergi pernapasan (\%) } \\
\cline { 2 - 4 } & Asma & Rinitis & $\begin{array}{c}\text { Asma disertai } \\
\text { rinitis }\end{array}$ \\
\hline Ada & 56 & 42 & 87 \\
Tidak ada & 44 & 58 & 13 \\
\hline Jumlah & 100 & 100 & 100 \\
\hline
\end{tabular}

Dermatophagoides pteronyssinus. Tungau debu yang paling banyak ditemukan di dalam rumah berasal dari ordo Acarii, subordo Astigmata dengan famili Pyroglyphidae, subfamili Dermatophagoidinae, genus Dermatophagoides, spesies Dermatophagoides farinae dan Dermatophagoides pteronyssinus, serta dari famili Echymyopodidae, genus Blomia, dan spesies Blomia tropicalis (Collof dan Spieksma 1992; Portnoy et al. 2013). Tungau debu di dalam rumah biasanya ditemukan di kursi, sofa, bangku, karpet, dan tempat tidur (Qamariah 2015). Makanan tungau berupa serpihan kulit manusia dan sisa remahan makanan yang jatuh di tempat biasanya tungau berkembang. Bagian tubuh tungau yang mengandung protein penyebab timbulnya alergi pernapasan berupa feses dari tubuhnya (Chan et al. 2015).

Setiap penderita alergi pernapasan belum tentu sama reaksinya terhadap setiap alergen dari 7 alergen uji tusuk kulit yang dicobakan dan urutan alergen yang menimbulkan sensitivitas pada penderita asma, rinitis, dan asma disertai rinitis berbeda-beda. Penderita rinitis lebih banyak sensitif pada alergen D.farinae, sedangkan penderita asma dan asma disertai rintis lebih sensitif pada alergen B.tropicalis (Tabel 4), penelitian Stanalad et al. (1994) melaporkan dari 167 pasien asma, $62 \%$ hasil uji tusuk kulitnya positif pada B.tropicalis, $38 \%$ positif pada D.pteronyssinus, dan D.farinae. Penelitian di Israel dari 117 pasien rinitis, 78\% sensitif terhadap D.farinae, $77 \%$ pada B.tropicalis, dan $75 \%$ pada D.pteronyssinus (Sade et al. 2010).

Berdasarkan Tabel 2, penderita rinitis lebih banyak berusia mulai dari 18 tahun dan pada usia tersebut biasanya seseorang berada pada jenjang pendidikan sebagai pelajar atau baru mulai bekerja sehingga lebih sering berada pada area sekolah, kampus, dan tempat kerja yang biasanya memiliki banyak kursi, suhu kurang dari $30^{\circ} \mathrm{C}$, dan kelembapan diatas $50 \%$ yang cocok bagi perkembangan D.farinaesehingga penderita rinitis cenderung lebih terkena paparan alergen D.farinae (Arlian et al. 1999; Sun et al. 2014; Qamariah 2015). Berbeda dengan penderita rinitis, penderita asma dan asma disertai rintis lebih banyak terkena paparan alergen B.tropicalis. B.tropicalis cenderung lebih banyak berada pada lantai dan karpet yang biasa kita temui di dalam rumah (Wahongan et al. 2017) dan berdasarkan Tabel 2, penderita asma atau asma disertai rinitis pada umumnya berusia

Tabel 4. Pasien penderita alergi pernapasan yang positif pada uji tusuk kulit di Poliklinik Alergi-Imunologi RSUPN-CM

\begin{tabular}{lccccccc}
\hline \multirow{2}{*}{ Alergi pernapasan } & \multicolumn{6}{c}{ Penderita yang positif terhadap alergen-alergen uji tusuk kulit (N) } \\
\cline { 2 - 8 } & Serbuk sari rumput & Kucing & Anjing & D. farinae & D. pteronyssinus & B. tropicalis & Kecoa \\
\hline Asma & 11 & 15 & 20 & 48 & 47 & 52 & 33 \\
Rinitis & 1 & 1 & 0 & 7 & 3 & 6 & 4 \\
Asma disertai & 8 & 8 & 6 & 14 & 12 & 15 & 6 \\
rinitis & & & & & & \\
\hline
\end{tabular}


mulai dari 40 tahun. Seseorang pada usia lebih dari 40 tahun biasanya lebih sering berada di rumah karena kebanyakan sudah menjadi ibu rumah tangga atau pensiunan sehingga penderita asma dan asma di sertai rinitis lebih cenderung terkena paparan alergen B.tropicalis.

Penderita alergi pernapasan lebih banyak sensitif terhadap alergen kecoa dibandingkan dengan alergen serbuk sari rumput, kecuali pada penderita asma disertai rinitis yang lebih banyak positif pada alergen serbuk sari rumput, walaupun jumlahnya tidak jauh berbeda dengan hasil uji pada alergen kecoa (Tabel 4). Sebagian besar penderita alergi pernapasan berusia dewasa yang produktif sampai mau memasuki usia lanjut. Saat usia produktif, seseorang banyak melakukan kegiatan di tempat seperti area sekolah, kampus, dan gedung perkantoran karena statusnya sebagai pelajar atau pekerja, sedangkan pada usia yang akan memasuki usia lanjut, seseorang biasanya sudah tidak bekerja dan lebih banyak di dalam rumah. Gedung pendidikan, perkantoran, dan berbagai macam permukiman seperti rumah, apartemen, dan villa biasanya memiliki kelembapan yang tinggi, memiliki banyak celah, dan mempunyai ruangan untuk gudang makanan seperti dapur. Tempat tersebut cocok bagi perkembangan kecoa (Lee et al. 2003; Mouchtouri et al. 2008; Rafiuddin 2016) sehingga penderita alergi pernapasan lebih cenderung terkena paparan alergen yang berasal dari kecoa. Feses dari kecoa mengandung alergen dan racun yaitu endotoksin yang dapat memicu terjadinya alergi (Lai 2017).

Penderita asma yang positif terhadap alergen kucing pada uji tusuk berjumlah 15 orang, dari 15 orang yang positif, ternyata hanya 6 orang yang memelihara kucing, dan penderita asma yang positif terhadap alergen anjing yang berjumlah 20 orang ternyata tidak ada satupun yang memelihara anjing (Tabel 4 dan 5). Penderita asma diduga terkena paparan alergen kucing peliharaannya dan alergen kucing serta anjing yang berasal dari luar rumah. Berbeda dari penderita asma, hasil wawancara dari penderita rinitis terdapat 6 orang memelihara kucing dan 1 orang memelihara anjing, namun hasil uji tusuk kulit menunjukkan hanya 1 orang yang positif terhadap alergen kucing dan tidak ada yang positif terhadap alergen anjing (Tabel 4 dan 5), sebagian besar penderita rinitis diduga tidak sensitif terhadap alergen yang berasal dari hewan

Tabel 5. Penderita alergi pernapasan di Poliklinik AlergiImunologi RSUPN-CM yang positif SPT dan memiliki hewan peliharaan

\begin{tabular}{lccc}
\hline Hewan peliharaan & \multicolumn{3}{c}{ Penderita alergi pernapasan $(\mathrm{N})$} \\
\cline { 2 - 4 } & Asma & Rinitis & $\begin{array}{c}\text { Asma disertai } \\
\text { rinitis }\end{array}$ \\
\hline Kucing & 6 & 6 & 4 \\
Anjing & 0 & 1 & 1 \\
\hline
\end{tabular}

peliharaannya, sedangkan pada penderita asma yang disertai rinitis, dari 8 orang yang positif terhadap alergen kucing, terdapat ada 4 orang yang memelihara kucing, dan dari 6 pasien yang positif terhadap alergen anjing, hanya 1 pasien yang memelihara anjing (Tabel 4 dan 5), penderita asma disertai rinitis diduga terkena paparan alergen kucing dan anjing yang berasal dari hewan peliharaannya dan luar rumah.

Penderita alergi pernapasan lebih cenderung sensitif terhadap alergen kucing karena kebanyakan orang lebih suka memelihara dan bersentuhan dengan kucing serta keberadaan kucing lebih banyak di dalam rumah, sedangkan anjing biasanya berada di luar rumah dan orang biasanya takut dan menghindari anjing sehingga masuknya alergen kucing ke dalam tubuh lebih besar kemungkinannya daripada alergen anjing. Alergen pada hewan kucing berasal dari bagian tubuhnya seperti rambut. Alergen utama kucing adalah Cat allergen 1 (CA 1). CA 1 biasanya berada di akar rambut pada kulit kucing (Bartholome et al. 1985). CA 1 diproduksi setiap hari pada kulit kucing sebesar $36 \mathrm{mU} / \mathrm{cm}^{2}$ (Dabrowski et al. 1990). Antigen CA 1 akan berikatan dengan antibodi IgE, ikatan yang terjadi menimbulkan respon sel mastosit yang berperan terhadap pelepasan mediator untuk terjadi inflamasi pada saluran pernapasan yang ditandai dengan gejala alergi pernapasan.

Selain alergen spesifik yang terdapat di lingkungan, faktor non-alergen yang kemungkinan juga berpengaruh terhadap timbulnya alergi pernapasan adalah emosi pasien. Emosi muncul bila dalam keadaan kesal atau cemas terhadap seseorang atau keadaan. Pengakuan para penderita alergi pernapasan yang datang ke RSUPN-CM pada umumnya merasakan sesak napas saat cemas atau kesal yaitu pada penderita asma dan asma disertai rinitis yang jumlahnya lebih dari 50\%, sedangkan penderita rinitis saja hanya separuh yang mengalami gejala rinitis ketika kesal dan cemas (Tabel 6).

Penelitian sebelumnya di Jakarta, dilaporkan sebanyak $88 \%$ penderita asma memiliki faktor pencetus serangan asma berupa perubahan emosi (Wahyuni dan Yulia 2014). Ketika dalam keadaan stress, seseorang mengalami kecemasan dan berpengaruh pada Hipotalamus Pituitari Anterior (HPA) untuk menghasilkan Hipotalamus Releasing Hormon (CRH) sebagai tanggapan terhadap sinyal stress (stressor) yang berasal dari lingkungan kemudian akan melepaskan hormon adrenokortikotropik (ACTH). ACTH berperan merangsang pelepasan hormon adrenalin diiringi dengan peningkatan sekresi kortisol. Kortisol menempel pada reseptor glukokortikoid dan menstimulasi sel T helper 2 (sel Th2) menghasilkan sitokin yaitu interleukin 4 (IL-4), IL-5, dan IL- 13. SitokinIL-13 dan IL-4 memicu sel 
B untuk memproduksi IgE. IgE yang dihasilkan akan menempel pada permukaan sel yang mengandung zat mediator inflamasi yaitu sel mastosit yang ada di saluran pernapasan, jika terjadi paparan alergen dari luar tubuh maka alergen akan berikatan dengan IgE lalu mengaktivasi sel mastosit melepaskan mediator inflamasi yaitu histamin dan leukotrin yang dapat menimbulkan rekasi inflamasi berupa perubahan mukus dan otot pada dinding pernapasan sehingga memicu terjadi reaksi klinis alergi berupa asma (Chen dan Miller 2007). Selain itu, keadaan stress juga dapat memicu peningkatan mediator inflamasi di bagian hidung sehingga berpeluang menginisiasi terjadianya reaksi alergi berupa rinitis (Nishioka et al. 2005).

Paparan asap rokok juga dapat merangsang munculnya gejala alergi pernapasan. Penderita rinitis alergi yang berobat di RSUPN-CM lebih dari 50\% menyatakan sensitif terhadap asap rokok, sedangkan penderita asma dan asma disertai rinitis kurang dari $50 \%$ yang menyatakan sensitif pada paparan asap rokok (Tabel 7). Asap rokok bersumber dari perokok aktif atau perokok pasif. Penderita alergi pernapasan yang memiliki keluarga dengan kebiasaan merokok di dalam rumah (perokok pasif) ternyata lebih sensitifjika terkena paparan asap rokok karena dapat menimbulkan reaksi alergi pernapasan.

Asap rokok di dalam rumah meningkatkan risiko penderita asma (Leuenberger et al. 1994). Seseorang yang memiliki ibu dengan kebiasaan merokok di rumah akan mengalami kenaikan hipersensitivitas bronkus dan penurunan fungsi paru yang merupakan faktor risiko untuk pengembangan gejala pernapasan seperti asma (Murray dan Morrison 1986). Selain itu, paparan asap rokok selama 15 menit juga dapat menimbulkan iritasi dan gejala rinitis (Biagini et al. 2006). Asap rokok meningkatkan kadar sitokin yang dihasilkan oleh sel Th2 dan menekan aktivitas sel Th1 sehingga sel Th2 menjadi lebih aktif, keadaan ini yang akan memicu terjadinya reaksi inflamasi karena adanya

Tabel 6. Faktor emosi terhadap jumlah penderita alergi pernapasan di Poliklinik Alergi-Imunologi RSUPN-CM

\begin{tabular}{lccc}
\hline Keadaan emosi & \multicolumn{3}{c}{ Penderita alergi pernapasan (\%) } \\
\cline { 2 - 4 } & Asma & Rinitis & $\begin{array}{c}\text { Asma disertai } \\
\text { rinitis }\end{array}$ \\
\hline Ada & 57 & 50 & 80 \\
Tidak ada & 43 & 50 & 20 \\
\hline Jumlah & 100 & 100 & 100 \\
\hline
\end{tabular}

Tabel 7. Pengaruh asap rokok terhadap penderita alergi pernapasan di Poliklinik Alergi-Imunologi RSUPN-CM

\begin{tabular}{lccc}
\hline Asap rokok & \multicolumn{3}{c}{ Penderita alergi pernapasan (\%) } \\
\cline { 2 - 4 } & Asma & Rinitis & $\begin{array}{c}\text { Asma disertai } \\
\text { rinitis }\end{array}$ \\
\hline Sensitif & 43 & 67 & 47 \\
Tidak sensitif & 57 & 33 & 53 \\
\hline Jumlah & 100 & 100 & 100 \\
\hline
\end{tabular}

ketidak seimbangan sel Tyang akan dilanjutkan dengan pengeluaran mediator inflamasi dan akan menimbulkan gejala klinis alergi pada saluran napas (Heens et al. 2009).

Kejadian alergi pernapasan dapat dipengaruhi oleh beberapa faktor pencetus. Alergi pernapasan dapat dicegah dengan cara mengendalikan diri agar terhindar dari faktor yang dapat menimbulkan gejala alergi pernapasan. Faktor yang berpengaruh terhadap kejadian alergi pernapasan adalah faktor genetik berupa riwayat penyakit alergi pernapasan yang diwariskan dari orang tua dan faktor lingkungan yang terdiri atas faktor non-alergen dan alergen. Faktor non-alergen berupa keadaan emosional penderita dan adanya paparan asap rokok terutama di dalam rumah, sedangkan faktor alergen berupa alergen spesifik seperti serbuk sari rumput, hewan peliharaan, tungau debu, dan kecoa yang dapat dilacak dan diketahui melalui uji tusuk kulit.

\section{KESIMPULAN}

Penderita alergi pernapasan yang berkunjung ke Poliklinik Alergi-Imunologi, Departemen Ilmu Penyakit Dalam, FKUI/RSUPN-CM lebih banyak diderita oleh perempuan. Sebagian besar pasien alergi pernapasan dapat dideteksi dengan uji tusuk kulit menggunakan alergen tungau debu. Setiap penderita alergi pernapasan belum tentu sama reaksinya terhadap setiap alergen dari 7 alergen pada uji tusuk kulit. Lebih dari $50 \%$ pasien alergi pernapasan memiliki riwayat alergi pernapasan dari orang tua. Keadaan emosi dan keberadaan asap rokok di dalam rumah bagi sebagian besarpasien alergi pernapasan dapat menjadi pencetus timbulnya gejala alergi pernapasan.

\section{DAFTAR PUSTAKA}

Alford SH, Zoratti E, Peterson EL, Maliarik M, Johnson CC. 2004. Parental history of atopic disease: disease pattern and risk of pediatric atopy in offspring. J Allergy Clin Immunol 114:1045-1050.

Alimuddin S. 2017. Uji diagnostik imunoglobulin E spesifik serum dibandingkan dengan uji tusuk kulit dalam mendiagnosis sensitisasi alergen tungau debu rumah dan kecoa pada pasien asma dan/atau rinitis alergi [Tesis]. Depok: Universitas Indonesia.

Arlian LG, Neal JS, Vyszenski-Moher DL. 1999. Reducing relative humidity to control the house dust mite Dermatophagoides farinae. J Allergy Clin Immunol 104:852-856.

Atmoko W, Faisal HKP, Bobian ET, Adisworo MW, Yunus F. 2011. Prevalens asma tidak terkontrol dan faktor-faktor yang berhubungan dengan tingkat kontrol asma di Poliklinik Asma Rumah Sakit Persahabatan, Jakarta. $J$ Respir Indo 31:53-60.

[Balitbangkes] Badan Penelitian dan Pengembangan Kesehatan. 2008. Riset Kesehatan Dasar (Riskesdas) 2007: LaporanNasional 2007. Jakarta:Badan Penelitian 
dan Pengembangan Kesehatan, Departemen Kesehatan, Republik Indonesia.

[Balitbangkes] Badan Penelitian dan Pengembangan Kesehatan. 2013. Riset Kesehatan Dasar (Riskesdas) 2013. Jakarta: Badan Penelitian dan Pengembangan Kesehatan, Kementrian Kesehatan Republik Indonesia.

Bartholome K, Kissler W, Baer H, Kopietz-Schulte E, Wahn U. 1985. Where does cat allergen 1 come from?. J Allergy Clin Immunol 76:503-506.

Biagini JM, LeMasters GK, Ryan PH, Levin L, Reponen T, Bernstein DI, Villareal M, Hershey GKK, Burkle J, Lockey J. 2006. Environmental risk factors of rhinitis in early infancy. Pediatr Allergy Immunol 17:278-284.

Bousquet J, Khaltaev N, Cruz AA, Denburg J, Fokkens WJ, Togias A, Zuberbier T, Baena-Cagnani CE, Canonica GW, van Weel C. 2008. Allergic Rhinitis and its Impact on Asthma (ARIA) 2008. Allergy 63:9-30.

Bousquet J, Heinzerling L, Bachert C, Papadopoulos NG, Bousquet PJ, Burney PG, Canonica GW, Carlsen KH, Cox L, Haahtela T. 2012. Practical guide to skin prick test in allergy to aeroallergens. Allergy 67:18-22.

Burke W, Fesinmeyer M, Reed K, Hampson L, Carlsten C. 2003. Family history as a predictor of asthma risk. $\mathrm{Am}$ J Prev Med 24:160-169.

Chan T, Ji K, Yim AK, Liu X, Zhou J, Li R, Yang KY, Li J, Li M, Law PT. 2015. The draft genome, transcriptome, and microbiome of Dermatophagoides farinae reveral a board spectrum of dust mite allergens. J Clin Immunol 135:539-548

Chen E, Miller GE. 2007. Stress and inflammation in exacerbations of asthma. Brain, Behavior, and Immunity 21:993-999.

Chiang $\mathrm{CH}, \mathrm{Wu} \mathrm{KM}, \mathrm{Wu} \mathrm{CP}$, Yan HC, Perng WC. 2005. Evaluation of risk factors for asthma in Taipei city. $J$ Chin Med Assoc 68:204-209.

Colloff MJ, Spieksma FTM. 1992. Pictorial keys for the identification of domestic mites. Clin and Experimental Allergy 22:823-830.

Cookson WOC, Moffatt MF. 2000. Genetics of asthma and allergic disease. Human Moleculer Genetics 9:23592364 .

Dabrowski J, Brempt XVD, Soler M, Seguret N, Lucciani P, Charpijn D, Vervloet D. 1990. Cat skin as an important source of Fel d I allergen. J Allergy Clin Immunol $86: 462-465$.

Davila I, Mullol J, Ferrer M, Bartra J, Cuvillo A D, Montoro J, Jauregui I, Sastre J, Valero A. 2009. Genetic aspects of allergic rhinitis. $J$ Investig Allergol Clin Immunol 19:25-31.

Ferliani, Sundaru H, Koesnoe S, Shatri H. 2015. Kepatuhan berobat pada pasien asma tidak terkontrol dan faktorfaktor yang berhubungan. Jurnal Penyakit Dalam Indonesia 2:140-150.

Hamano N, Terada N, Maesako K, Numata T, Konno A. 1998. Effect of sex hormones on eosinophilic inflammation in nasal mucosa. Allergy and Asthma Proc 19:263-269.

Heens GLT, van der Velden U, Loos BG. 2009. Cigarette smoking enhances $\mathrm{T}$ cell activation and a $\mathrm{Th} 2$ immune response; an aspect of the pathophysiology in periodontal disease. Cytokine 47:157-161.

Herdi. 2011. Gambaran faktor pencetus serangan asma pada pasien asma di poliklinik patu dan bangsal paru RSU Dr. Soedarso Pontianak [Skripsi]. Pontianak: Universitas Tanjungpura

Hikmah N, Dewanti IDAR. 2010. Seputar rekasi hipersensitivitas (alergi). Stomatognatic 7:108-112.

Johansson SGO, Bieber T, Dahl R, Friedmann PS, Lanier BQ, Lockey RF, Motala C, Martell JAO, Platts-Mills TAE, Ring J. 2004. Revised nomenclature for allergy for global use: report of the nomenclature review committee of the world allergy organization, october 2003. J Allergy Clin Immunol 113:832-836.
Lai KM. 2017. Are cockroaches an important source of indoor endotoxins?. Environ Res Public Health 14:110.

Lampalo M, Jukic I, Bingulac-Popovic J, Marunica I, Petlevski R, Pavlisa G, Popovie-Grle S. 2017. Polymorphism $4 \mathrm{G} / 5 \mathrm{G}$ of the plasminogen activator inhibitor 1 gen as a risk factor for the development of allergic rhinitis symptoms in patients with asthma. Eur Arch Otorhinolaryngol 274:2613-2619.

Lee DK, Lee WJ, Sim JK. 2003. Population densities of cockroaches from human dwellings in urban areas in the Republic of Korea. JVE 28:90-96.

Leuenberger P, Schwartz J, Ackermann-Liebrich U, Blaser K, Bolognini G, Bongard JP, Brandil O, Braun P, Bron C, Brutsche M. 1994. Passive smoking exposure in adults and chronic respiratory symtoms. Am J Respir Crit Care Med 150:1222-1228.

Ludfi AS, Agustina L, Fetarayani D, Baskoro A, Gatot S, Effendi C. 2012. Asosiasi penyakit alergi atopi anak dengan atopi orang tua dan faktor lingkungan. Jurnal Penyakit Dalam 13:53-62.

Lumbanraja PLH. 2007. Distribusi alergen pada penderita rinitis alergi di departemen THT-KL FK USU/ RSUP H. Adam Malik Medan [Tesis]. Medan: Universitas Sumatra Utara.

Mennella C, Dickstein DP. 2016. Metformin-induced type 1 hypersensitivity in a child with antipsychotic-induced weight gain. J Child Adolesc Psychopharmacol 20:106107.

Mouchtouri VA, Anagnostopoulou R, Voyadjoglou AS, Theodoridou K, Hatzoglou C, Kremastinou J, Hadjichristodoulou C. 2008. Surveillance study of vector species on board passenger ships, risk factors related to infestations. BMC Public Health 8:1-8.

Murray AB, Morrison BJ. 1986. The effect of cigarette smoke from the mother on bronchial responsiveness and severity of symptoms in children with asthma. J Allergy Clin Immunol 77:575-581.

Nishioka K, Okano M, Ichihara Y, Ichihara N, Nishizaki K. 2005. Immunosuppressive effect of restraint stress on the initiation of allergic rhinitis in mice. Int Arch Allergy Immunol 136:142-147.

Osman M. 2003. Therapeutic implications of sex differences in asthma and atopy. Arch Dis Child 88:587-590.

Portnoy J, Miller JD, Williams PB, Chew GL, Miller JD, Zaitoun F, Phipatanakul W, Kennedy K, Barnes C, Grimes C. 2013. Environmental assessment and exposure control of dust mites; a practice parameter. Ann Allergy AsthmaImmunol 111:465-507.

Postma DS. 2007. Gender differences in asthma development and progression. Gender Medicine 4:113-146.

Price D, Bjermer L, Bergin DA, Martinez R. 2017. Asthma referrals: a key component of asthma management that need to be addressed. J Asthma Allergy 10:209-223.

Priyanto H, Yunus F, Wiyono WH. 2011. Studi perilaku kontrol asma pada pasien yang tidak teratur di Rumah Sakit Persahabatan. J Respir Indo 31:138-149.

Qamariah N. 2015. Ragam jenis, distribusi dan kelimpahan tungau debu rumah pada wilayah permukiman di Bogor [Tesis]. Bogor: Institut Pertanian Bogor.

Rafiuddin AT. 2016. Telaah infestasi lipas (insecta: Dictyoptera) pada busdan kaitannya dengan pengelolaan moda transportasi [Tesis]. Bogor: Institut Pertanian Bogor

Rengganis I, Hartana A, Guhardja E, Djauzi S, Budiarti S. 2008. Sensitivitas terhadap serbuk sari pada pasien alergi pernapasan. Majalah Kedokteran Indonesia 58:327-334.

Sade K, Roitman D, Kivity S. 2010. Sensitization to Dermatophagoides, Blomia tropicalis, and other mites in atopic patients. Journal of Asthma 47:849- 852. 
Schoefer Y, Schafer T, Meisinger C, Wichmann HE, Heinrich J. 2008. Predictivity of allergic sensitization (RAST) for the onset of allergic diseases in adults. Allergy 63:8186.

Sellaturay P, Nasser S, Ewan P. 2015. The incidence and features of systemic reaction to skin prick tests. Ann Allergy Asthma Immunol 30:1-5.

Stanaland BE, Fernandez-Caldas E, Jacinto CM, Trudeau WL, Lockey RF. 1994. Sensitization to Blomia tropicalis: skin test and cross-reactivity studies. J Allergy Clin Immunol 94:452-457.

Sun J, Shen L, Chen J, Yu J, Yin J. 2014. Mite and Boolouse fauna from vacuumed dusr samples from beijing. Allergy Asthma Immunol 6:257-262.

Usman I, Chundrayetti E, Khairsyaf O. 2015. Faktor risiko dan faktor pencetus yang mempengaruhi kejadian asma pada anak di RSUP Dr. M. Djamil Padang. Jurnal Kesehatan Andalas 4:392-397.

Utama DS. 2010. Hubungan antara jenis dengan manifestasi klinis rinitis alergika [Tesis]. Semarang: Universitas Diponegoro.
Vrieze A, Postma DS, Kerstjens HAM. 2007. Perimenstrual asthma: a syndrome without known cause or cure. $J$ Allergy Clin Immunol 112:271-282.

Wahongan GJP, Sembel DT, Tulung M, Satoto TBT. 2017. Types and density of dust mites found among different habitats in houses in North Sulawesi Province, Indonesia. JEZS 5:681-685.

Wahyuni AH, Yulia. 2014. Prevalensi faktor-faktor pencetus serangan asma pada pasien asma di salah satu rumah sakit di Jakarta [Skripsi]. Depok: Universitas Indonesia.

[WHO] World Health Oeganization. 2017. Asthma.Tersedia di: http://www.who.int/mediacentre/factsheets/fs307/en/ [Data akses: 10 Juni 2017]

Wistiani, Notoatmojo H. 2011. Hubungan pajanan alergen terhadap kejadian alergi pada anak. Sari Pediatri 13:185-190. 